\title{
TRADISI SASTRA DIKILI DALAM PELAKSANAAN UPACARA ADAT MAULIDAN DI GORONTALO
}

\author{
Moh. Karmin Baruadi \\ Fakultas Sastra dan Budaya Universitas Negeri Gorontalo \\ Jl. Taman Surya No. 8 Gorontalo \\ email: karminbaruadi11@gmail.com
}

\begin{abstract}
:
This article reveals the implementation of dikili or maulud tradition based on Gorontalo's culture. It is analyzed using sosio-cultural approach and empirical observation on any custom event of dikili. The result points out that in fact the social and cultural society culture of Gorontalo places dikili as an important practice containing religious values to manage the society life behavior. Islamic aesthetic norms constitute the symbolic translation of the belief and conception of God reflected in the form of dzikr or remembrance. Such a dominant Islamic teaching obeyed by Gorontalo's Islamic community becomes the source of the art as modikili. Ergo, Gorontalo's society mainly appreciates Islamic traditions maintained for good. That Islamic values established as slogan manifesting Gorontalo's culture identical with Islam namely 'adati hula hula'a. to sara'a., sara'a. hula hula'a. to kuru'ani 'or the custom based on Qur'an.
\end{abstract}

Artikel ini bertujuan mengungkapkan pelaksanaan kegiatan dikili atau maulud Nabi menurut tradisi Gorontalo. Pengkajian dilakukan dengan pendekatan sosio-kultural melalui penelusuran literatur dan pengamatan empirik terhadap setiap peristiwa adat terkait dikili. Hasil kajian menunjukan bahwa berdasarkan kenyataan, sosial dan budaya masyarakat suku Gorontalo menempatkan dikili sebagai sesuatu yang penting dan mengandung nilai-nilai religius dalam mengatur perilaku hidup masyarakat. Norma-norma keindahan Islam merupakan penerjemahan secara simbolis terhadap kepercayaan dan pemahaman kepada Tuhan yang tercermin dalam formula zikir. Nilai-nilai 
ajaran Islam yang dominan dipatuhi oleh masyarakat Islam Gorontalo tersebut merupakan sumber acuan yang melahirkan kesenian seperti modikili. Hal inilah yang menyebabkan masyarakat Gorontalo sangat menghargai tradisitradisi terutama yang bernuansa islami yang selamanya tetap dilestarikan. Nilai-nilai Islami tersebut telah dikukuhkan melalui semboyan yang menjadi cerminan budaya Gorontalo yang identik dengan Islam yaitu 'adati hula-hula'a to sara'a, sara'a hula-hula'a to kuru'ani' atau adat bersendi syarak dan syarak bersendi al Quran.

Keywords: modikili, maulud tradition, Islamic culture

\section{Pendahuluan}

Ide dan gagasan manusia banyak yang hidup bersama dalam suatu masyarakat. Menurut Koentjaraningrat gagasan tersebut tidak lepas dari unsur lainnya yang saling berkaitan sebagai suatu sistem budaya (cultural system) yang dipertahankan secara berkelanjutan (Koentjaraningrat, 1980: 201). Termasuk ke dalam hal ini wujud gagasan yang terjelma dalam kebudayaan daerah. Wujud kebudayaan daerah menyangkut berbagai aspek kehidupan masyarakat di seluruh daerah di Indonesia. Setiap daerah memiliki ciri khas kebudayaan yang berbeda, begitu pun halnya dengan daerah Gorontalo. Masyarakat Gorontalo sebagai salah satu etnis di Indonesia memiliki kebudayaan sebagai peninggalan nenek moyang terdahulu yang terpatri dalam tradisi yang berbentuk sastra atau lebih dikenal dengan nama sastra daerah. Ditinjau dari penggunaan bahasanya berdasarkan hasil penelitian Tuloli didapatkan klasifikasi sastra daerah Gorontalo menurut penggolongan (Tuloli dkk., 1983: 10):

1. Ragam sastra yang menggunakan bahasa Gorontalo lama atau bahasa adat.

2. Ragam sastra yang menggunakan bahasa Gorontalo umum.

3. Ragam sastra yang menggunakan campuran kata-kata Arab dan kalimatkalimat al Quran dengan bahasa Gorontalo/Melayu.

4. Ragam sastra yang menggunakan campuran bahasa Gorontalo dengan bahasa Melayu.

Berdasarkan klasifikasi di atas modikili atau dikili yang dalam bahasa Indonesia dikenal dengan zikir termasuk klasifikasi yang ketiga yaitu ragam sastra yang menggunakan campuran kata-kata bahasa Gorontalo, bahasa Melayu dan Arab yang bersumber dari al Quran. Sastra zikir ini dalam tradisi 
Melayu merupakan salah satu di antara sekian banyak sastra pengaruh Islam. Nilai universal Islam adalah sifat moral yang ditandai dengan pembedaan yang baik dan yang buruk. Nilai yang mempertentangkan yang baik dan buruk ini umumnya muncul dalam tema-tema sastra (Nasr, 1989: 45). Berbudaya, berseni dan bersastra dengan azas Islam dapat diinterpretasikan sebagai suatu wujud beribadah kepada Allah (Baruadi, 2012:306). Dengan demikian nilai-nilai universal agama Islam itu menjadi patokan atau tema utama karya sastra pengaruh Islam itu. Sastra diciptakan karena Allah untuk kepentingan manusia yang terarah kepada kesejahteraan dan kebahagiaan hidup manusia di dunia dan akhirat (Ahmad, 1981: 3)

Ciri-ciri konsep sastra Islam itu yang menonjol adalah masalah akhlak, moral, etika dan hidup kemanusiaan (Ahmad, 1981: 6-7). Sastra pada umumnya mengandung aspek-aspek moral dan ahlak ini. Kemunculannya bisa dikaji dalam penokohannya, ide dan temanya, serta ungkapan-ungkapan yang bernilai ajaran Islam. Sebagai bagian dari "Puisi Melayu Tradisional" puisi berbentuk zikir (dikili), antara lain berisi puji-pujian kepada Allah, puji-pujian kepada Nabi, pantun berisi ajaran, dan mantra serta doa (Piah, 1989: 526). Dari hasil penelitiannya di Afrika Finnegan memberikan beberapa ciri sastra yang berhubungan dengan agama (Finnegan, 1978: 167-170). Ciri-ciri itu adalah: (1) isinya berkaitan dengan agama, yaitu Ketuhanan dan ajaran (syariat), (2) penceritanya ahli agama, (3) dilakukan dalam upacara agama. Hal ini sama dengan pendapat Ben-Annos bahwa makna satra harus dilihat dari konteks budayanya (Ben-Annos dkk., 1975: 105-106). Maknanya bisa dirujuk pada tempat dan situasi pengucapannya.

Perkataan zikir berasal dari bahasa Arab dan dalam bahasa Gorontalo masyarakat lebih akrab dengan nama dikili, modikili atau (kegiatan) modua (berdoa) yang dilakukan pada saat peringatan maulid Nabi Muhammad SAW. Dikili diucapkan atau dilagukan oleh tukang dikili pada waktu memperingati kelahiran Nabi Muhammad SAW setiap bulan Rabiul Awal, sehingga muncul arti zikir maulidan. Tradisi ini diucapkan secara berlagu yang berisi pujaan dan kisah tentang Nabi Muhammad, terdiri atas dua bentuk yaitu syair dan narasi (kisah). Dikili ditinjau dari segi isi merupakan pujaan kepada Nabi, berisi kisah Nabi Muhammad sejak dalam perut Siti Aminah sampai lahir, Nabi disusukan oleh Halimatus Sa'adiyah dan juga menceritakan sifat Nabi ketika masih kecil. Pengucapan atau pembacaan dikili secara khusus dilakukan oleh tukang dikili (ta modikilia). Tukang dikili ialah orang yang telah mengetahui dikili baik dalam menghapal isinya maupun sekaligus melagukannya. 
Menurut Heijer dalam bahasa Melayu perkataan zikir lebih dominan digunakan disamping kata zikir, dike atau jike (Piah, 1989:3). Disebutkan pula bahwa zikir dalam tradisi Melayu digunakan sebagai: (1) puji-pujian kepada Allah diucapkan dengan atau tanpa lagu dengan intonasi yang berulang, (2) lagu atau nyanyian dengan pantun berarti suatu kegiatan pujian kepada Allah, diucapkan tanpa lagu, (3) doa atau pujian berlagu, biasanya disampaikan dalam perayaan maulid Nabi, (4) zikir juga dapat berarti gugusan kata-kata berupa doa yang diungkapkan. Adapun bentuk dikili yang mengandung ketentuan di atas diperlihatkan dalam contoh berikut.

Assalamun alaika
Zainal anbiya'i
Assalamun alaika
Atakal atukiya'i
Assalamun alaika
Assafal assufiya'i
Assalamun alaika
Azakal azukiya'i
Assalamun alaika
Minni rabbissama'i
Assalamun alaika
Daimbila inkida'i

Berdasarkan keterangan di atas dapat disimpulkan bahwa dikili (zikir) mengandung pengertian pujian kepada Allah yang diucapkan berulang, bentuknya berupa doa yang kadang diucapkan dengan berlagu dan ada juga yang tidak berlagu, dilakukan dengan suatu upacara terutama terlihat dalam perayaan Maulid Nabi Muhammad SAW. Perlakuan dikili (zikir) dianggap merupakan bagian dari amal ibadah kepada Tuhan untuk memuji kebesaranNya, mengagungkan kekuasaan-Nya, serta sebagai puji-pujian yang ditujukan kepada Nabi Muhammad selaku utusan-Nya untuk keselamatan bagi manusia di dunia dan akhirat.

Dikili termasuk sastra Gorontalo pengaruh Islam yang bersamaan dengan sastra Islam lainnya seperti me'eraji, barjanji digunakan dalam kegiatan berbudaya di Gorontalo. Gorontalo merupakan salah satu daerah di Indonesia yang menempatkan budayanya identik dengan Islam. Hal inilah yang menyebabkan budaya di Gorontalo sarat dengan muatan-muatan ajaran Islam yang berlandaskan pada al Quran dan Hadits. Semua tata cara dalam 
upacara menurut budaya Gorontalo bernuansa Islami yang terpatri dalam pola syariat sebagai landasan adat Gorontalo. Pola syariat dimaksud dapat diklasifikasi atas 186 pola adat yang berdasarkan kedudukan dan rumpunnya dapat digolongkan menurut 7 rumpun adat, terdiri dari: (a) pola adat ketika sang ibu mengandung jabang bayi dan saat bayi dilahirkan disebut Awal pertumbuhan, (b) pola adat ketika sang anak menjelang akil balik, (c) pola adat ketika dilangsung perkawinan menurut tradisi Gorontalo, (d) pola adat ketika seseorang menderita sakit sampai saat kematian menjelang, (e) pola adat penerimaan tamu, (f) pola adat menyelenggarakan atau membina kehidupan sosial kemasyarakatan dan agama, dan (g) pola adat membina silaturahim dalam pergaulan antara masyarakat (Baruadi, 2012:300).

\section{Klasifikasi Dikili}

Dari segi fungsi membuat klasifikasi zikir atas (a) zikir maulid yang pelaksanaannya pada saat memperingati hari maulud, (b) zikir berarak, digunakan saat mengarak pengantin dan tamu penghormatan dan (c) zikir rebana yang dilaksanakan dengan menggunakan alat tabuh rebana saat berjalan menuju tempat upacara (Piah, 1989: 527). Selain itu ahli yang sama dari segi bentuk juga membuat klasifikasi zikir atas zikir laba, berjanji dan zikir Nabi Allah yang dijelaskan di bawah ini.

a. Zikir Laba, adalah zikir yang bahasanya merupakan perpaduan atau campuran antara bahasa Arab dan bahasa Melayu. Terdapat pengutamaan unsur seni dalam zikir ini sehingga dikenal ada zikir yang sesuai ketentuan persyaratan zikir (zikir yang betul) dan bermakna serta ada juga zikir yang disusun secara bebas dan tidak bermakna.

b. Zikir Barjanji, merupakan terjemahan dalam barjanji Arab Melayu sesuai terjemahan sewajarnya. Kata-katanya berbentuk puisi bebas, dari jenis qasidah (puisi Arab) yang menggunakan irama tunggal (monorhyme) tidak saja dalam satu untaian, bahkan dalam satu buku dari awal hingga akhir.

c. Zikir Nabi Allah, bentuk ini lebih baik dan sempurna kata-katanya. Ungkapan-ungkapan yang digunakan tersusun dari baris-baris yang panjang dan mengandung empat hingga enam perkataan. Sama halnya dengan barjanji zikir Nabi Allah merupakan adaptasi langsung dari bahasa/sastra Arab. Perbedaannya adalah jika barjanji lebih dekat dengan qasidah sebagai salah satu puisi Arab sedangkan zikir Nabi Allah lebih puitis lebih indah dan lebih dekat dengan puisi Melayu. 
Secara keseluruhan tema dan isi zikir merupakan alat untuk menyampaikan pengajaran agama Islam dan merupakan petikan-petikan singkat beberapa kisah dan isi penceritaanya serta kata-katanya lebih puitis dan indah. Zikir Nabi Allah selain lagu dan iramanya aspek yang diutamakan ialah kelebihan dan ketrampilan pezikir mengeluarkan suara yang tinggi terutama pada bagianbagian suatu untai zikir (Piah, 1989: 548). Hal demikian dapat dibuktikan pada tradisi modikili di Gorontalo. Saat melantunkan zikir yang biasanya dilakukan pada malam hari maka pada semua masjid di daerah Gorontalo akan terdengar lantunan zikir yang kadang meninggi, kadang merendah yang dilakukan bersahut-sahutan dan berkesinambungan antara satu pezikir dan pezikir lainnya tanpa kenal lelah. Kebolehan dan kemampuan seperti ini bersama keindahan serta kesakralan yang terlihat di dalamnya menyebabkan tradisi dikili menjadi suatu khas budaya yang diminati dan dihormati. Dengan isi yang mengandung nasehat dan pengajaran, zikir-zikir itu berhasil mengingatkan masyarakat pengguna untuk menaati dan menjalan ajaran agama bersandarkan pada nilai-nilai keagamaan yang lebih baik untuk menuntunnya menjadi muslim yang sempurna. Sesungguhnya kandungan dan maksud zikir adalah untuk menyampaikan pengajaran yang baik dan amanat-amanat yang berfungsi sebagai pedoman hidup masyarakat.

\section{Kedudukan dan Fungsi Dikili}

Penggunaan bahasa Gorontalo yang bercampur dengan bahasa Arab dan digunakan dalam peristiwa budaya di Gorontalo menyebabkan dikili dapat disebut sebagai bagian dari sastra daerah Gorontalo. Hal ini sama dengan pantun yang ketika digunakan dalam kegiatan budaya Gorontalo dan menggunakan campuran bahasa Melayu dan Gorontalo menjadikan sastra ini juga diangap sebagai salah satu ragam sastra daerah dan disesuaikan namanya menjadi paantungi. Modikili dikenal sebagai suatu tradisi selalu diidentikkan dengan peringatan Kelahiran Nabi Muhammad yang sudah ratusan tahun dijalani oleh masyarakat. Meski di daerah lain juga memiliki tradisi serupa, namun di daerah Gorontalo lebih terasa khas karena tradisi ini dilakukan dengan unik dan menjadi kewajiban setiap orang untuk melaksanakannya dengan asumsi dan harapan untuk bisa mendapatkan syafaat darinya. Peringatan hari kelahiran Nabi Muhammad SAW selalu menjadi peristiwa yang paling dinanti-nantikan oleh umat muslim di daerah Gorontalo. Peringatan maulid ini ditandai dengan lantunan dikili dilaksanakan semalam suntuk, yaitu dimulai setelah shalat Isya hingga pagi hari pukul 09.00 WITA atau pukul 10.00 WITA. Pelaksanaan 
dikili bagi masyarakat yang menganut paham ini dianggap merupakan suatu keharusan, dan oleh karenanya sebahagian besar masjid di Gorontalo selalu melaksanakannya. Kecintaan dan kesetiaan tertuang dalam alunan dikili, yang dibarengi dengan hiasan kue-kue kolombengi dan tolangga atau wadah untuk menempatkan kue-kue dimaksud yang dihias dengan keindahan yang bernuansa islami. Bagi pezikir yang sudah melaksanakan kegiatan modikili semalam suntuk juga diberikan sedekah (sadaka). Sedekah ialah uang atau barang yang disediakan panitia pelaksana dikili yang diberikan kepada orang yang berdikili. Sedekah berbentuk uang dibagikan menjelang doa penutup dan disertai sesajian berupa kue dalam bentuk kecil yang ditaruh pada sebuah wadah yang disebut toyopo.

Peringatan Maulid Nabi Muhammad SAW semarak dengan berbagai macam kegiatan mulai dari tradisi walimah (kue berhias) yang penuh dengan makna simbolik serta juga dikili yang dibaca/dilantun usai sholat Isya bersama pembacaan riwayat perjalanan Nabi Muhammad SAW dalam bahasa Gorontalo hingga Subuh. Para ulama berdakwah dan umarapun berpidato mengenai esensi kepemimpinan Nabi Muhammad SAW. Pidato tersebut bukan sekedar bagian dari seremoni peringatan tapi sebagai bagian dari renungan, menganalisis dan memahami dengan baik suri teladan Nabi Muhammad SAW serta agama Allah SWT yang diajarkannya kepada dunia.

Dikili yang dimiliki oleh para pezikir biasanya diperoleh dalam bentuk naskah. Dalam bentuk naskah dikili berfungsi sebagai media yang diciptakan oleh pembuatnya untuk mengabadikan buah pikiran, perasaan dan pengetahuannya agar ia dapat membaca dan memahaminya kembali apabila suatu saat dibutuhkan. Naskah-naskah tersebut setelah dibaca orang lain yang akhirnya jika orang tersebut tertarik kemudian berusaha memperolehnya baik dengan cara menyalinnya sendiri, atau menyuruh orang lain menyalin untuk dimiliki. Pada peralihan generasi atau setelah beralih kepemilikan naskah itu, maka selanjutnya fungsi naskah beralih (berkembang) ke fungsi lain misalnya, dianggap sebagai pegangan seseorang atau keluarga sebagai benda warisan. Naskah dapat pula digunakan sebagai bahan yang diperjualbelikan sehingga mendatangkan keuntungan bagi pemilik.

Untuk kepentingan ilmu pengetahuan maka naskah dapat pula dipakai sebagai objek penelitian, dan sebagainya. Fungsi naskah itu pada waktu dahulu adalah: (1) sebagai pegangan bagi kaum bangsawan atau para turunan raja untuk mengetahui asal usul, silsilah serta sejarah leluhur mereka, (2) menjadi alat pendidikan bagi masyarakat terutama mereka yang sering mendengar dan 
membacakannya, (3) untuk menikmati hasil seni terutama seni sastra, dan (4) untuk keperluan praktis bagi masyarakat (Manyambeang, 1987: 6-7).

Secara lengkap dilihat dari fungsi naskahnya baik sebagai benda maupun isinya seperti umumnya naskah-naskah Gorontalo, maka naskah dikili mempunyai fungsi sebagai berikut:

a. Sebagai buku pegangan seseorang dan keluarga. Naskah dikili sebagaimana halnya naskah Gorontalo pada umumnya juga dimiliki oleh seseorang atau keluarga untuk kepentingan pribadi mereka sebagai pegangan. Pada umumnya naskah-naskah itu seolah-olah dianggap sebagaimana layaknya kitab suci disimpan, dipelihara atau dirawat sebaik mungkin, sehingga jika sewaktu-waktu dibutuhkan untuk dibaca atau dipakai, naskah tersebut tetap ada. Naskah dikili mengandung pelajaran agama yang bisa meningkatkan dan memperkuat keimanan mereka, maka dengan memilikinya seseorang atau suatu keluarga merasa mendapatkan kepuasan batin tertentu berupa kepuasan batin dalam beragama.

b. Sebagai benda yang bisa mendatangkan keuntungan. Memiliki naskah dikili juga dianggap bisa mendatangkan rejeki atau keuntungan bagi pemiliknya. Pemilik naskah biasanya mengakui dengan memiliki naskah dikili secara turun temurun mereka merasakan keuntungan bahkan meyakini akan menduduki jabatan penting di kampung baik sebagai kepala desa, carik desa atau sebagai pemangku adat. Jabatan-jabatan terpandang ini dianggap merupakan suatu berkah bagi mereka. Menurut anggapan sebagian masyarakat bahwa untuk menjadi seorang khalifah atau pemimpin umat atau masyarakat maka kita harus mengetahui segala-galanya, dan hal itu hanya bisa kita dapatkan melalui naskah-naskah.

c. Sebagai benda warisan. Bagi para penyalin yang mewariskan profesi ini kepada keturunannya naskah dikili dapat dijadikan sebagai benda warisan. Sebagai benda warisan naskah dikili diperlakukan sebagai barang berharga seperti layaknya yang dilakukan terhadap benda-benda warisan yaitu disimpan di tempat yang dianggap aman, dijauhkan dari tempat yang kotor dan berdebu, jauh dari air, api dan sebagainya. Para pemilik naskah dikili umumnya kurang mengetahui cara-cara menyimpan naskah yang baik terutama yang menyangkut pembuatan ramuan obat-obatan yang diperlukan untuk menjaga naskah agar tetap baik dan utuh. Cara yang mereka lakukan cukup dengan menyimpan naskah di lemari atau di tempat tertentu yang dianggap aman yang jauh dari air dan api. Adapun jika diketahui mereka naskahnya akan rusak maka cepat-cepatlah mereka menyalin naskah tersebut dan naskah yang lama itu dimusnahkan. 
d. Sebagai bahan pelajaran agama bagi masyarakat. Naskah dikili bukan hanya sebagai media yang disimpan untuk dibaca sewaktu-waktu demi kepuasan batin pemiliknya. Akan tetapi naskah ini juga dipakai atau dibaca untuk diperdengarkan kepada masyarakat terutama saat memperingati perayaan Maulid Nabi karena di dalamnya terkandung pelajaran agama, etika dan moral yang dapat memperkuat keimanan masyarakat. Dengan mengetahui ini maka masyarakat diingatkan untuk senantiasa tidak melupakan kewajibannya melaksanakan perintah Allah SWT dan menjauhi segala larangannya.

e. Sebagai alat untuk keperluan praktis masyarakat. Pembacaan naskah dikili juga dilaksanakan untuk tujuan-tujuan praktis dianggap sakral dan dipercaya dapat (1) menghindarkan diri dari malapetaka dunia, (2) mendapatkan berkah dari Allah SWT, (3) diberikan kemurahan dalam rezeki, dan (4) permohonan kepada Allah terkabulkan seperti yang telah diuraikan pada bagian pendahuluan.

f. Sebagai media untuk menikmati hasil seni budaya masyarakat. Pembacaan naskah dikili tidak setiap orang mampu melaksanakannya, karena saat membaca dibutuhkan teknik-teknik pembacaan dengan variasi lagu tertentu yang hanya bisa diketahui apabila dipelajari dan dilatih. Oleh karena itu dikili memiliki nilai seni yang tinggi yang tidak sembarang orang dapat membacanya. Hal demikian berlaku karena pembacaan dengan berlagu dimaksudkan untuk mengajak pendengar menyimak dengan sebaik-baiknya isi yang terkandung dalam dikili.

Dengan adanya penjelasan di atas maka dengan membaca atau pun mendengarkan dikili maka akan dapat diketahui dan dinikmati sebuah hasil seni budaya masyarakat Gorontalo yang diciptakan pada masa lalu. Dilihat dari kandungan teksnya dikili pada prinsipnya memiliki fungsi utama untuk membesarkan asma Allah sebagai bagian dari ibadah dan fungsi mengagungkan Nabi Muhammad. Nabi Muhammad SAW merupakan Nabi yang disanjung dan merupakan panutan umat Islam. Muhammad adalah pesuruh dan Nabi pilihan Allah SWT untuk menuntun umat manusia ke jalan yang benar. Kesempurnaan perilaku seorang manusia tercermin dari tingkah laku Nabi Muhammad SAW seperti yang kita baca dalam kisah-kisah tentang Nabi Muhammad. Demikian pula dalam dikili ini fungsi untuk mengagungkan Nabi Muhammad itu pun sangat menonjol. Hal ini dimaksudkan agar umat Islam lebih dalam rasa cintanya kepada junjungannya Nabi Muhammad SAW. 


\section{Tradisi Dikili dalam Nuansa Budaya Gorontalo}

a. Tata Cara Pelaksanaan

Penduduk Gorontalo adalah penduduk yang terkenal sebagai umat yang sangat kuat memegang teguh ajaran agama Islam. Kaitan antara agama Islam dan kebudayaan di dalam masyarakat Gorontalo sangat erat. Agama sangat mempengaruhi budaya Gorontalo dan banyak unsur-unsur ajaran agama yang diperlakukan menjadi budaya masyarakat Gorontalo. Sejak dahulu daerah Gorontalo dikenal sebagai salah satu daerah budaya di Indonesia. Unsur-unsur budaya daerah ini tercermin dalam peninggalan budaya seperti pakaian pengantin yang mirip dengan pakaian pengantin Parsi, pakaian raja dan pemangku adat, rumah adat dan tempat kedudukannya, senjata kerajaan serta bahasa daerah yang terus dipelihara. Kesenian dan kesusastraannya beraneka ragam, sedangkan di bidang pertanian daerah Gorontalo terkenal dengan sistem pengolahan tanah yang menunjukkan ciri-ciri khusus.

Sistem pemerintahan kerajaan dahulu dalam batas-batas tertentu, masih tercermin dalam adat-istiadat daerah. Suatu sistem demokrasi sedari zaman dahulu telah terwujud dalam masyarakatnya, pemangku adat, penguasa agama yang disebut kadli serta penguasa keamanan yang disebut Apitalau. Seorang penguasa atau raja pada zaman dahulu yang dianggap memerintah hanya untuk kepentingan sendiri dan bukan untuk rakyat, dapat diturunkan dari tahtanya setelah melalui prosedur adat berdasarkan konsensus dan dilaksanakan oleh pemangku adat melalui syair (tuja'i) yang dikhususkan untuk itu.

Dikili merupakan salah satu budaya Gorontalo yang berunsur kesusastraan dan bernafaskan Islam. Oleh karena itu, untuk kepentingan syiar Islam maka pada setiap tahun diadakan perayaan membaca dan melantunkan dikili atau kegiatan modikili. Waktu pelaksanaan biasanya di masjid-masjid yaitu pada hari peringatan Maulid Nabi Muhammad SAW. Pelaksanaannya di masjid dilaksanakan dalam suatu uapacara adat yang dihadiri oleh pejabat atau dalam istilah adat disebut pembesar negeri. Setelah selesai maka akan dilanjutkan dengan kegiatan berzikir semalam suntuk yang menampilkan para pezikir (haulu). Kegiatan pengucapan dan pembacaan naskah dikili mengikuti tata cara tertentu yang sudah ditetapkan secara adat. Umumnya dalam adat Gorontalo segala sesuatu sudah diatur, setiap orang tinggal melaksanakannya. Dalam hubungan dengan peradatan, Gorontalo menganut aturan seperti yang diungkapkan dalam semboyan:

"Aadati ma dili-dilito bolo mopo'aito, aadati ma hunti-huntinga bolo mopodembingo, aadati ma hutu-hutu bolo mopohutu". 
Artinya:

Adat sudah dipolakan, tinggal menyambung, adat sudah digunting, tinggal menempelkan, adat sudah ada tinggal melaksanakan (Baruadi, 2012:36).

Di samping itu dalam buku "Tata Upacara Adat Gorontalo" Botutihe menyebutkan:

"Aadati; didu boli-didu boli, didu toma-tomalia limongoli, didu boli-boliya, aadati lo hunggiya to tilayo to huliya, dipo ta lo boboliya, hipakuwa lo tadiya, adati lo lahuwa, to tilayo to ta'uwa, dipo ta lo bobohuwa, hi tadiya, hipakuwa".

Artinya:

Adat istiadat, belum berubah, jangan lagi kalian polakan, jangan lagi direkayasa. Adat milik negeri, dari bawah sampai ke atas, belum ada perubahan, disumpah dan diabadikan (Botutihe dkk., 2003:i).

Dikili, prosesi unik yang begitu mengagungkan Nabi Muhammad SAW. Prosesi modikili diawali atau dimulai dengan alunan zikir (dikili), shalawat, dan puji-pujian kepada Allah untuk sang Nabi yang "berulang tahun" hingga pagi menjelang siang. Selama semalam suntuk, para imam, ulama, dan pegawai syara' yang ditunjuk, melantunkan dikili. Tentu saja dengan sedikit istrahat untuk sekedar meneguk secangkir teh atau kopi untuk menjaga agar tubuh tetap hangat dan suara tetap terdengar lantang. Di sinilah wujud pengagungan dan pengorbanan umat muslim di Gorontalo kepada sosok seorang Nabi yang menjadi suri teladan dalam setiap perilakunya. Seolah ingin menunjukkan betapa dalamnya rasa cinta mereka terhadap Nabi Muhammad SAW. Masyarakat yang tidak ikut melantunkan dikili pun sebagian berusaha tetap terjaga untuk menyiapkan hidangan bagi para pelantun dikili (haulu) yang ingin beristirahat sejenak. Sepiring bubur ayam dan secangkir teh atau kopi serta beberapa macam penganan dirasa cukup untuk mengembalikan semangat yang mulai digerogoti rasa kantuk. Adapun tata cara atau prosesi pelaksanaan kegiatan modikili yaitu:

a. Setelah sholat Isya, para ulama atau para pezikir melaksanakan doa, di daerah kita Gorontalo biasanya dikenal dengan mongadi shalawati. Seperti halnya orang yang lagi berulang tahun, awalnya dimulai dengan doa syukuran. Seperti itulah bentuk dari mongadi shalawati tersebut.

b. Setelah itu dilanjutkan dengan ceramah. Ceramah yang akan disampaikan oleh penceramah bukan hanya ceramah yang sembarangan, namun ceramah tersebut berisi tentang riwayat kelahiran Nabi Muhammad SAW.

c. Setelah penceramah menyampaikan ceramah tersebut, apabila waktu telah menunjukkan pukul 09.00 WITA atau 10.00 WITA langsung dilanjutkan dengan berzikir atau modikili. Zikir ini biasanya akan berlangsung semalam 
suntuk hingga pukul 07.00 pagi.

d. Setelah berzikir semalam suntuk, esok harinya dilanjutkan dengan doa penutup.

Usai prosesi dikili, masyarakat di sekitar masjid yang merayakan maulid berkumpul di halaman masjid untuk berbagi bahkan berebutan kue yang diisi dalam sebuah tolangga. Tolangga adalah sebuah wadah besar yang dihiasi dengan berbagai macam jenis kue dan makanan seperti nasi putih, nasi kuning, nasi bilindi, telur, dan lain-lain. Tolangga inipun ada yang khusus untuk dibagibagikan kepada masyarakat, ada pula yang khusus diberikan kepada para Imam, ulama, maupun pegawai syara', sebagai "imbalan" atas pengorbanan mereka melantunkan dikili selama semalam suntuk. Di sinilah bagian yang paling unik dalam prosesi peringatan Maulid Nabi di Gorontalo, menyaksikan indahnya hasil kreativitas masyarakat dalam menghias tolangga-nya masingmasing. Apalagi menyaksikan hiruk-pikuknya pembagian (mungkin lebih tepat disebut perebutan) kue walimah (walimah berasal dari bahasa Arab, artinya perayaan. Sedangkan kue walimah di Gorontalo sering diartikan sebagai kue yang menghiasi tolangga), seperti yang diperlihatkan dalam gambar berikut ini.
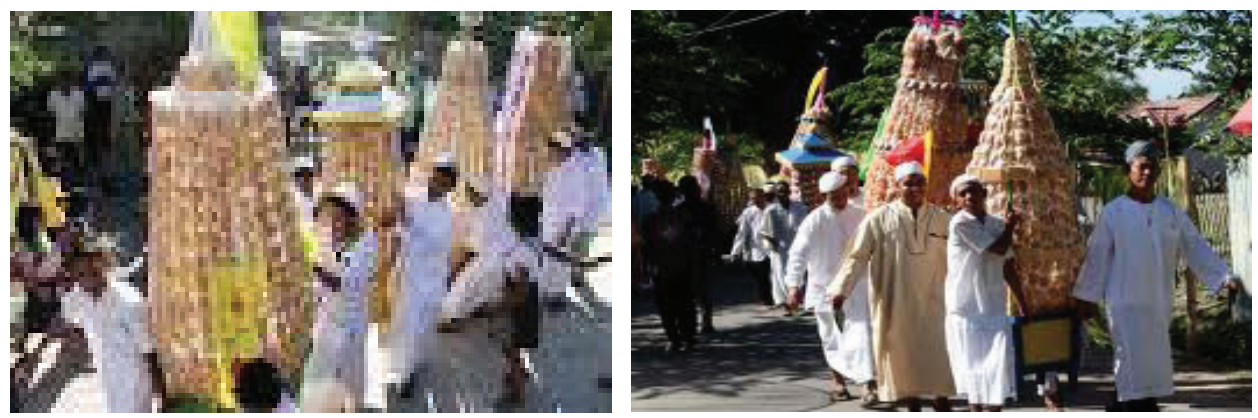

Gambar 1. Prosesi dikili (perayaan maulid Nabi)

\section{b. Prosesi Adat Dikili}

Proses pelaksanaan acara modikili secara adat dilaksanakan melalui tahapantahapan tertentu sesuai adat. Oleh karena itu sebelum perayaan tiba masyarakat mengadakan musayawarah terlebih dahulu. Hal-hal yang dimusyawarahkan menyangkut (1) penentuan hari dan tanggal perayaan, (2) pembagian tugas pelaksanaan perayaan berupa pembentukan panitia, (3) penentuan tempat pelaksanaan, (4) penentuan perlengkapan yang dibutuhkan, (5) penentuan tata 
laksana perayaan, dan (6) penentuan biaya dan sumber biaya.

Panitia yang dibentuk oleh pihak pemerintah saat pelaksanaan bertugas mengatur mulai dari penerimaan tamu, mengatur konsumsi, dan mencatat tamu yang wajib diberikan sedekah. Panitia bukan sebagai pelaksana adat, mereka bekerja sama dengan pemangku adat mempersiapkan dan memperlancar pelaksanaan baik sebelum maupun saat berlangsungnya perayaan. Sedangkan yang berperan sebagai pelaksana adat adalah para pemangku adat yang dalam istilah Gorontalo disebut Baate.

Tradisi dikili yang dilaksanakan secara adat dapat pula dilihat dari tempat duduk. Semua masyarakat yang hadir termasuk khalifah harus duduk bersila. Tempat duduk adat atau huhulo'a lo aadati dibagi menurut stratifikasi masyarakat.

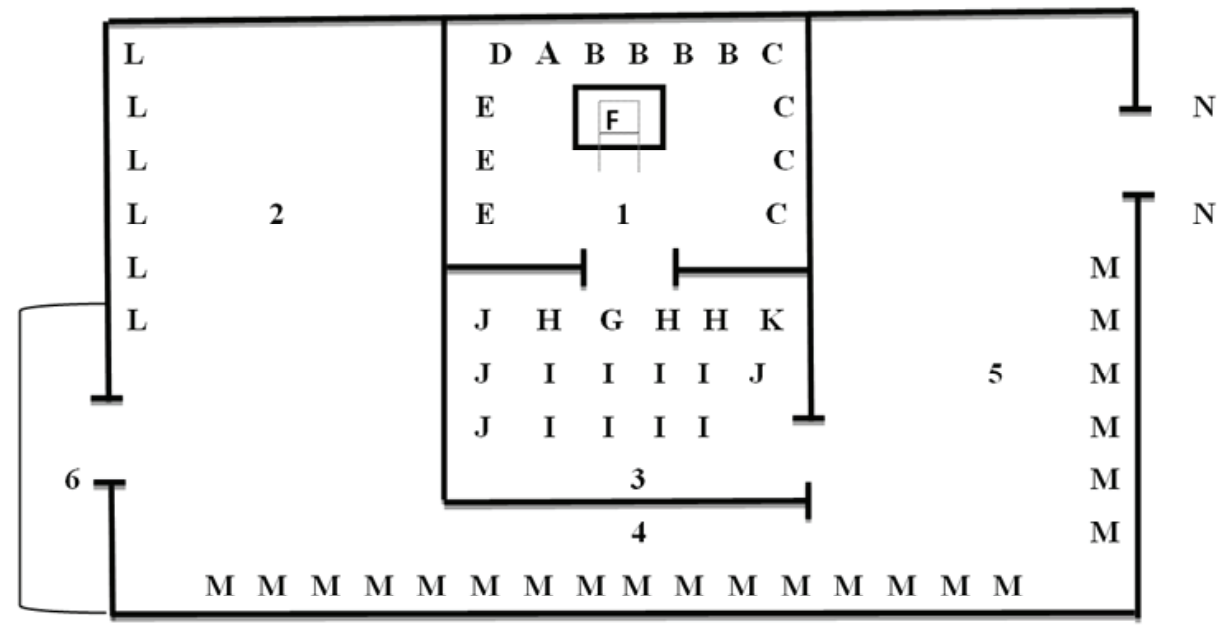

Gambar 2. Skema tempat duduk adat dalam acara modikili

Keterangan :

$1=$ Huhulo'a lo Bulita (Ruang Utama Pria)

$2=$ Bulita Utama Wanita (tempat duduk para isteri)

$3=$ Ruangan Pezikir

$4,5=$ Ruang tempat masyarakat biasa

$6=$ Ruang konsumsi

A $\quad=$ Khalifah (Bupati, Walikota/Pembesar Negeri)

$\mathrm{B}=$ Wali-wali mowali $/$ Pejabat Teras

C $=$ Pimpinan instansi jawatan

$\mathrm{D}=$ Kadli $/$ Pemimpin Agama

$\mathrm{E} \quad=$ Instansi/Jawatan/Tokoh Masyarakat 


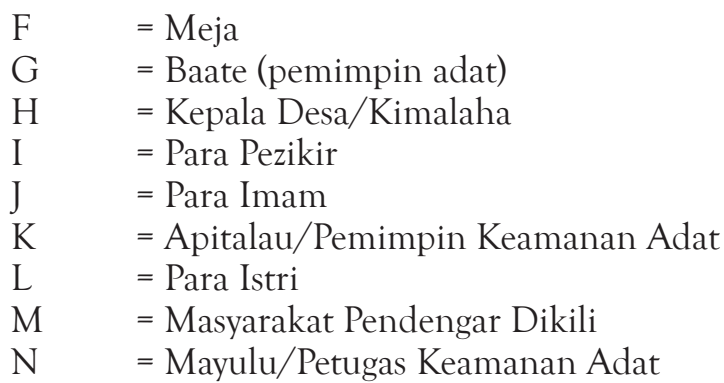

Tempat duduk diatur sedemikian rupa sesuai tertibnya dalam jabatan dan fungsi masyarakat. Ruangan untuk pelaksanaan kegiatan modikili disebut Huhulo'a lo Aadati. Sedangkan ruangan untuk para pembesar negeri disebut Huhulo'a lo Bulita. Ruangan ini dibagi atas ruangan Bulita Utama Pria yang dikhususkan bagi pria dan Bulita Utama Wanita dihususkan bagi para istri yang mendampingi suaminya ke acara ini. Khusus untuk tempat duduk khalifah dialas dengan kasur dan permadani yang sisinya diberi bantal. Apabila telah masuk ruangan tersebut dilarang melakukan gerakan-gerakan yang mengganggu pelaksanaan adat. Siapa saja yang ingin masuk atau keluar dari ruangan itu harus memberi hormat lebih dahulu kepada khalifah yang dalam istilah adat disebut molubo. Demikian pula tempat duduk lainnya diatur menurut ketentuan adat. Siapa saja yang duduk di ruangan tersebut harus berhadapan langsung dengan Khalifah, tidak diperkenankan membelakangi khalifah. Di belakang dari petugas dan pelaksana adat duduk anggota masyarakat yang ingin mendengarkan dikili. Di pintu luar masjid berdiri petugas keamanan adat (mayulu). Selama khalifah masih berada di dalam Huhulo'a lo Bulita, mayulu tidak bisa beranjak dari tempatnya, dan selama pemimpinnya (Apitalau) masih ada dalam masjid Mayulu tidak bisa merapat ke tempat duduk khalifah.

Semua masyarakat yang berada dalam lingkungan Hululo'a lo Aadati baik pelaksananya atau hanya bermaksud mendengarkan diharuskan memakai pakaian yang sopan. Bagi kaum pria diharuskan memakai baju kin, celana panjang dilengkapi dengan sarung yang dililit dalam keadaan terlipat dua pada pinggang di luar celana panjang serta memakai kopiah. Sedangkan bagi kaum wanita harus berpakaian baju muslim serta memakai kerudung. Bagi khalifah, pemangku adat/Baate, pemuka agama, kepala desa, dan dinas jawatan lainnya memakai pakaian yang telah ditentukan secara adat.

Sama halnya dengan memperingati hari-hari besar Islam lainnya tata cara pelaksanaan upacara perayaan maulid dengan acara inti pembacaan naskah dikili secara adat menuruti rangkaian kegiatan sebagai berikut (Baruadi, 2012: 
38):

1. Mopo'ota. Acara ini berupa pemberitahuan kepada pemerintah setempat tentang pelaksanaan perayaan maulid, disampaikan secara adat oleh dua orang pegawai syara' (salada'a). kegiatan ini dilaksanakan empat hari sebelum acara dilaksanakan.

2. Moloduo, Kegiatan ini berupa undangan oleh pemangku adat kepada Butulo Toulongo atau Tiga Serangkai Adat, yang terdiri dari:

a. Bubato atau pemerintah dalam hal ini khalifah.

b. Pemimpin agama (Kadli).

c. Pemimpin Keamanan (Apitalau).

3. Lenggota lo Pohutu (pelaksanaan acara). Kegiatan ini dilaksanakan menurut tahapan-tahapan tertentu yang pelaksanaannya secara adat terdiri dari:

a. Molo'opu, berupa penjemputan khalifah di rumah kediaman atau yiladia oleh pegawai syara' dan Apitalau diikuti oleh para pelaksana adat dan undangan yang diiringi dengan genderang oleh Mayulu, dilengkapi pula dengan melagukan sastra pujian yang disebut sa'ia lao-lao.

b. Mopobulio atau mengatur tempat duduk menurut tertibnya. Acara ini dilaksanakan setelah Khalifah dan para undangan tiba di masjid. Setelah duduk akan diiringi dengan sa'ia hulo-hulo'o.

c. Mopodungga lo yilumo, menyuguhkan minuman ringan yang dilaksanakan oleh pemangku adat menurut tertibnya.

d. Mopoluduo lo u yilumo, mempersilahkan khalifah dan para undangan minum.

e. Mopotouli lo u yilumo, menjemput kembali peralatan sajian minuman setelah acara minum selesai.

f. Mopoma'lumu, memaklumkan kepada pembesar negeri (khalifah) bahwa acara Maulid Nabi akan dimulai yang didahului dengan mohaulu (tahlilan). Pemangku adat maju ke depan khalifah sambil melakukan sembah (molubo)

g. Mohaulu (tahlilan), yang mengikuti tahapan acara: momuata bohu (menjemput bara api), mopoloduo lo bohu (mempersilahkan acara memulai tahlilan) yang dipimpin oleh imam, mahaulu dan ditutup dengan du'a (doa) oleh pegawai syara' diiringi dengan hawasif oleh hadirin.

4. Pelaksanaan dikili, mengikuti urutan acara sebagai berikut:

a. Mopoma'lumu, maklumat kepada pembesar negeri bahwa acara pembacaan naskah dikili akan dimulai

b. Momuata bohu, menjemput bara api secerek air dan satu tempat air (loyang) yang dihiasi dengan bunga dayo sebagai perlengkapan upacara. 
Selanjutnya bara api tadi ditaruh di suatu tempat yang agak besar dialas dengan bunga pinang (buloyo) kemudian diletakkan di atas meja. Di atas meja itu telah disediakan naskah dikili yang akan dibaca.

c. Mopoloduo, mempersilahkan kepada para tokoh agama untuk memulai, yang biasanya akan didahului oleh kadli sebagai pembaca yang pertama, kemudian secara berganti akan dilakukan oleh para imam dan tokoh agama yang lain.

d. Mongabi, mongabi biasanya juga disebut dengan molomela hulo'a (mengubah cara duduk adat). Mongabi merupakan pertanda bahwa upacara kebesaran adat telah selesai. Dengan selesainya acara mongabi maka peserta telah bebas dari ikatan peradatan. Hal ini dilakukan karena tidak semua orang yang duduk di huhulo'a lo aadati akan bertahan sampai pembacaan naskah dikili selesai. Oleh karena itu, biasanya setelah pembaca yang pertama selesai dan akan dilanjutkan dengan pembaca yang kedua acara mongabi ini dilaksanakan, yang kemudian akan dilanjutkan kemudian setelah persidangan adat dibubarkan. Setelah itu biasanya khalifah dan dinas jawatan sudah diperkenankan untuk beristirahat. Bagi yang ingin mendengarkan dikili hingga selesai bisa tetap tinggal di dalam masjid.

\section{Pantangan atau Sanksi Adat Modikili}

Adat adalah gagasan kebudayaan yang terdiri dari nilai-nilai kebudayaan, norma kebiasaan, kelembagaan dan hukum adat yang lazim dilakukan di suatu daerah atau merupakan suatu aturan yang sudah berlaku di suatu daerah. Apabila adat ini tidak dilaksanakan atau dilanggar, maka akan mendapat hukuman. Hukumannya pun bervariasi dan sesuai dengan adat yang telah dilanggar.

Hukum adat yang berlaku di setiap daerah berbeda-beda meskipun tak jarang terjadi kemiripan. Adat Gorontalo pada dasarnya sama seperti adat pada suku-suku lain, tetapi dengan beberapa perbedaan atau kekhasan yang membedakannya. Kekhasan ini terutama disebabkan karena masyarakat Gorontalo sejak dahulu dominan menganut agama Islam. Di daerah kita Gorontalo terdapat berbagai macam kebudayaan dan adat istiadat yang menghasilkan hukum adat yang beraneka-ragam. Salah satunya adalah kebudayaan mopodikili.

Berdasarkan anggapan masyarakat sanksi yang didapatkan apabila adat modikili tidak dilaksanakan, dosa karena mengabaikan kewajiban agama, kemudian akan ada hal buruk yang akan menimpa diri kita, selanjutnya akan terjadi kerancuan yang menimbulkan sanksi tak tertulis oleh masyarakat setempat 
terhadap pelaku yang dianggap menyimpang. Karena menurut mereka adat modikili ataupun kebudayaan ini sudah menjadi tradisi masyarakat sejak ratusan tahun yang lalu. Tradisi ini sudah dianggap sebagai kebiasaan dalam suatu komunitas masyarakat yang dilakukan secara terus menerus hingga menjadi sebuah rutinitas yang mempunyai konsekuensi tersendiri apabila dilanggar atau tidak dilaksanakan. Bahkan di beberapa sisi tradisi ini dianggap sebagai tradisi tertua yang begitu dihormati dan laksanakan secara terus menerus. Karena mopodikili ini bukan hanya sekedar perayaan yang begitu saja, tapi ini merupakan peringatan untuk memperingati hari kelahiran Nabi Muhammad SAW, dimana beliau meruapakan suri teladan bagi kita umatnya. Dalam konteks adat Gorontalo, budaya ataupun tradisi mopodikili ini merupakan suatu nilai yang selalu beriringan dengan norma-norma keislaman dan menjadi semacam hukum tersirat di dalam aktifitas keseharian masyarakat. Maka tidak heran bila Gorontalo memberikan alternatif sanksi adat kepada para pelanggar hukum bila memungkinkan. Jadi tidak dapat dipungkiri, apabila kita masyarakat meninggalkan tradisi atau tidak melaksanakan tradisi tersebut maka akan menimbulkan akibat buruk baginya bahkan bagi masyarakat di dunia ataupun di akhirat.

\section{Makna dan Nilai Kultural Dikili}

Peringatan Maulid Nabi Muhammad SAW bukan sekedar peringatan ataupun perayaan semata. Tapi peringatan tersebut mempunyai makna tersendiri bagi kita umat manusia, khususnya umat yang melaksanakan peringatan kelahiran Maulid Nabi Muhammad SAW tersebut. Seperti telah disampaikan di atas di daerah Gorontalo peringatan ini sering disebut mopodikili (dikili). Makna mopodikili (dikili) atau makna peringatan Maulid Nabi Muhammad SAW bagi masyarakat Gorontalo antara lain:

a) Kita seluruh umat manusia yang ada dimuka bumi ini diperintahkan oleh Allah untuk mengintrospeksi diri secara total. Maka sebagai bentuk introspeksi tersebut adalah melalui kegiatan berzikir (modikili).

b) Kita diperintahkan untuk berorientasi agar menjadi seorang pemimpin yang jujur dengan mngambil keteladanan sifat mulia dari Nabi Muhammad SAW, diantaranya adalah shiddiq sehingga beliau diberi gelar al Amin atau orang yang dapat dipercaya. Sifat shiddiq yang utama adalah sidqul qalb atau kejujuran hati nurani, sidqul hadits atau jujur dalam ucapan atau perkataan dan sidqul amal atau benar dalam perbuatan.

c) Kita diperintahkan untuk bisa tunduk dan patuh terhadap ajaran yang 
disampaikan oleh Nabi Muhammad SAW.

d) Kita diperintahkan untuk selalu ingat kepada Allah, karena dengan selalu mengingat Allah merupakan cara yang paling sederhana untuk mengingatkan kita semua dimanapun kita berada, untuk tidak berbuat maksiat, selalu berada di jalan yang benar dan dalam lindungan Allah. Karena tanpa ijin Allah kita tidak akan pernah ada, tanpa ijin Allah kita tidak akan bisa mendapat rahmat-Nya, dan tanpa ijin Allah kita tidak bisa berbuat apaapa.

e) Di dalam berzikir atau modikili pengucapan tasbih yang terus-menerus mengantarkan seseorang kepada ketenangan jiwa dan batin tatkala mendapatkan sesuatu hal yang tidak baik atau buruk. Selain itu, kita semakin meyakini bahwa segala hal yang buruk maupun baik, merupakan kehendak Allah SWT.

f) Dan dengan kita melaksanakan adat modikili ini, dapat meningkatkan kualitas ketakwaan kita kepada Allah SWT dan kecintaan kita terhadap Rasulullah.

Pada intinya kita semua umat manusia, diperintahkan oleh Allah SWT untuk tetap berada dijalan-Nya serta kita bisa meneladani perilaku ataupun sikap dari Nabi Muhammad SAW. Tidak menutup kemungkinan bahwa Allah ingin mengajarkan kepada hamba-Nya yang ikhlas beribadah kepada-Nya untuk dapat melakukan ibadah walaupun dengan kalimat yang ringan dan mudah untuk diucapkan. Jadi kesimpulannya yaitu, alunan zikir yang dilantunkan pada saat peringatan kelahiran Nabi Muhammad SAW (modikili) mempunyai makna yang begitu besar buat kita semua umat manusia.

Kegiatan berzikir saat memperingati hari maulid ditandai oleh adanya penyediaan kue berhias yang disebut walimah. Walimah itu sendiri merupakan sajian atau hidangan yang diberikan oleh masyarakat kepada ulama, imam atau yang ikut melantunkan zikir atau dikili tersebut. Penyediaan barang sesajian tersebut bermakna wujud pengagungan dan pengorbanan umat muslim di Gorontalo kepada sosok seorang Nabi yang menjadi suri teladan dalam setiap perilakunya. Barang tersebut diberikan kepada para Umara dan Ulama yang dianggap sebagai penerus ajaran para Nabi sesuai panduan ayat menyebutkan ati'ullah, wa ati'u al rasul wa uli al amri min kum. Hal tersebut juga sebagai pertanda bahwa para pemimpin dan ulama harus menjadi teladan perilaku yang diperlihatkan oleh para Nabi. Disamping itu seolah ingin menunjukkan betapa dalamnya rasa cinta mereka terhadap Nabi Muhammad SAW, makna 
dari walimah yaitu ekspresi kebahagiaan yang diwujudkan dalam karya seni dan spirit kerja yang tinggi. Totalitas dalam maulid Nabi tidak membuat masyarakat jadi miskin, setiap tahun makin ramai, bahkan setiap perayaan Walimah masyarakat selalu antusias merayakannya.

Bentuk perilaku yang disadari sebagai bagian dari cara hidup tertentu dalam masyarakat muslim berkaitan dengan kesadaran untuk selalu mengadakan hubungan dan pendekatan dengan penciptanya. Berkaitan dengan modikili, terdapat nilai kultural atau nilai budaya yang dapat diambil dari modikili. Nilai budaya Islam sebagai pandangan hidup telah melatarbelakangi perilaku umatnya. Hal tersebut tergambar dalam nuansa modikili misalnya, nampak jelas bagaimana norma-norma keindahan dengan latar belakang Islam. Nilai budaya yang terdapat pada zikir (modikili) bisa kita lihat melalui atau diwadahi lewat syair iringan, zikir yang dilantunkan dengan baik dan indah didengar serta penataan masjid mulai dari awal pelaksanaan sampai diakhiri dengan pemberian hidangan berupa walimah oleh masyarakat kepada ulama, imam atau yang ikut berzikir dan itu merupakan perwujudan kreativitas dalam bentuk koreografi yang mendapat pengaruh budaya yang bercorak Islam.

Norma-norma keindahan Islam merupakan penerjemahan secara simbolis terhadap kepercayaan dan pemahaman kepada Tuhan yang tercermin dalam formula zikir. Nilai-nilai ajaran Islam yang dominan dalam masyarakat Islam merupakan sumber acuan dalam lahirnya kesenian seperti modikili. Demikian halnya dalam proses pertumbuhan dan perkembangannya.

Nilai-nilai ajaran Islam akan menjadi bingkai penuangan keindahan dalam kesenian Islam. Sehingga kekuatan nilai tersebut tidak hanya menjiwai dan mewarnai tetapi memberi bentuk terhadap keseniannya. Menjadi salah satu ekspresi budaya manusia, seni modikili akan selalu hadir dan dibutuhkan dalam segala aspek kehidupan. Sehingga persoalan yang ada di dalamnya berkaitan dengan masalah cita budaya dari masyarakat yang menghasilkannya. Sebagai mahluk berbudaya manusia memiliki potensi yang bisa dikembangkan sesuai dengan kondisi budaya setempat.

\section{Simpulan}

Zikir merupakan salah satu sarana atau strategi pendekatan kepada Allah SWT, yang dalam pelaksanaannya dilakukan secara individu dan dapat pula dilaksanakan secara bersama-sama. Dalam budaya Gorontalo istilah ini disebut dikili. Berbeda dengan budaya lainnya kegiatan modikili (berzikir) dikenal sebagai suatu tradisi yang selalu diidentikkan dengan peringatan 
kelahiran (maulud) Nabi Muhammad yang sudah ratusan tahun dijalani oleh masyarakat. Meski di daerah lain juga memiliki tradisi serupa, namun di daerah Gorontalo lebih terasa khas karena tradisi ini dilakukan dengan unik dengan suatu upacara adat dan menjadi kewajiban setiap orang untuk melaksanakannya dengan asumsi dan harapan untuk bisa mendapatkan syafaat dari Nabi Muhammad SAW.

Dengan membaca atau pun mendengarkan dikili maka akan dapat diketahui dan dinikmati sebuah hasil seni budaya masyarakat Gorontalo yang diciptakan pada masa lalu. Dilihat dari kandungan teksnya dikili pada prinsipnya memiliki fungsi utama untuk membesarkan asma Allah sebagai bagian dari ibadah dan fungsi mengagungkan Nabi Muhammad. Muhammad adalah pesuruh dan Nabi pilihan Allah SWT untuk menuntun umat manusia ke jalan yang benar. Kesempurnaan perilaku seorang manusia tercermin dari tingkah laku Nabi Muhammad SAW. Demikian pula dalam dikili ini fungsi untuk mengagungkan Nabi Muhammad itu pun sangat menonjol. Hal ini dimaksudkan agar umat Islam lebih dalam rasa cintanya kepada junjungannya Nabi Muhammad SAW.

Berdasarkan adat Gorontalo pelaksanaan dikili mengikuti tata cara tertentu yang sudah ditetapkan secara adat yang segala sesuatu sudah diatur dan tinggal melaksanakannya. Dalam hubungan dengan peradatan, Gorontalo menganut aturan seperti yang diungkapkan dalam semboyan Aadati ma dili-dilito bolo mopo'aito, aadati ma hunti-huntinga bolo mopodembingo, aadati ma hutu-hutu bolo mopohutu. Artinya adat sudah dipolakan, tinggal menyambung, adat telah digunting tinggal menempelkan, adat sudah tertera tinggal melaksanakan.

Kegiatan berzikir saat memperingati hari maulid ditandai oleh adanya penyediaan kue berhias yang disebut walimah. Makna dari walimah yaitu ekspresi kebahagiaan yang diwujudkan dalam karya seni dan spirit kerja yang tinggi. Penyediaan walimah dianggap oleh masyarakat sebagai wujud kesyukuran atas karunia yang diberikan dan karenanya setiap manusia yang mengaku muslim wajib menyediakannya. Dengan demikian secara totalitas penyelenggaraan maulid Nabi dengan penyediaan walimah yang melimpah tidak membuat masyarakat jadi miskin, bahkan setiap tahun makin ramai dan masyarakat selalu antusias merayakannya.

Dalam kegiatan berzikir nilai-nilai ajaran Islam menjadi bingkai penuangan keindahan dalam kesenian Islam. Kekuatan nilai tersebut tidak hanya menjiwai dan mewarnai tetapi memberi bentuk terhadap keseniannya, 
menjadi salah satu ekspresi budaya manusia. Karena keindahannya maka seni berzikir (modikili) akan selalu hadir dan dibutuhkan dalam segala aspek kehidupan karena berkaitan dengan masalah cita budaya dari masyarakat yang menghasilkannya dengan suatu asumsi bahwa sebagai mahluk berbudaya pada hakikatnya manusia memiliki potensi yang bisa dikembangkan sesuai dengan kondisi budaya setempat.

\section{Daftar Pustaka}

Ahmad, Shahnan, 1981. Kesusastraan dan Etika Islam. Kuala Lumpur: Fajar Bakti SDN. BHD.

Baruadi, Moh. Karmin. 2012. Me'eraji. Gorontalo: Ideas Publishing.

Baruadi, Moh. Karmin. 2012. Sendi Adat dan Eksistensi Sastra Pengaruh Islam dalam Nuansa Budaya Lokal Gorontalo. El-harakah, Jurnal Budaya Islam. Malang: UIN Maulana Malik Ibrahim.

Ben-Annos, Dan dan Kenneth S. Goldstein. 1975. Folklore Performance and Communication. Mouton: The Hague.

Botutihe, Medi dan Farha Daulima. 2003. Tata Upacara Adat Gorontalo. Gorontalo: Pemerintah Daerah.

Finnegan, Ruth. 1978. Oral Literature in Africa. Nairobi: Oxford University Pressouledge.

Koentjaraningrat. 1980. Pengantar Ilmu Antropologi. Jakarta: Aksara Baru.

Manyambeang, Abd. Kadir. 1987. Pengantar Filologi. Ujung Pandang: Universitas Hasanuddin.

Nasr, S.H.1989. Falsafah Kesusastraan dan Seni Halus. Terjemahan oleh Baharudin Ahmad. Kuala Lumpur: Dewan Bahasa dan Pustaka.

Tuloli, Nani dkk. 1983. Nilai-nilai Budaya dalam Sastra Daerah Gorontalo, Suatu Orientasi Sastra dan Filologi. Pidato Ilmiah pada Dies Natalis FKIP Unsrat. Gorontalo: FKIP.

Piah, Mat Harun. 1985. Puisi Melayu Tradisional (Goore dan Fungsi). Kuala Lumpur: Harol Watson and Viney. 